\title{
Truce likely in battle over 'DNA-chip' patent rights
}

[PARIS] A leading British scientist and a US biotechnology company say they are keen to reach an amicable settlement over the European patent rights to so-called 'DNA-chips', a key genome technology, rather than face a protracted court battle in which either party might lose all.

The patent, which was granted in 1989, is held by Ed Southern of the University of Oxford, and is being challenged by Affymetrix of San Francisco. It covers the technique of using oligonucleotide arrays as a testing platform, and Southern has applied for a similar patent in the United States.

Southern invented the technique of Southern blotting, but never patented it; "I'm learning from my mistakes," he says. He is setting up a company, Oxford Gene Technology, to commercialize DNA-chip technology, particularly for disease genotyping and antisense applications.

But he says that he "feels quite strongly" that the company should adopt a "reasonable" licensing policy. "It's a broad-based core technology, and it would be wrong for one company to hold a monopoly position."

The DNA chip patent, however, is being challenged by Affymetrix, and independently by six other companies - including Hoffmann La Roche and Abbott Laboratories in a formal opposition that may take several years to work its way through the European Patent Office.

The principle of the technology is similar to that of gel electrophoresis-based techniques of DNA hybridization. But it is much easier to automate and gives much higher throughputs. By combining light-directed synthetic techniques (photolithography) developed in the semiconductor industry with conventional oligonucleotide synthetic chemistry, it allows the automated production of up to 100,000 specific DNA sequences on the surface of microchips in a few hours.

Such chips are widely considered one of the most promising genome technologies. Using hybridization, the sequence of genes, and indeed whole genomes, can be quickly compared. This opens up possibilities for deducing the function of genes, and developing genetic tests and antisense therapies.

An indication of the interest in the technology comes from the creation last month of a consortium by Affymetrix, Bristol-Myers Squibb and Millennium Pharmaceuticals to support a $\$ 40$-million five-year research programme aimed at developing gene-based technologies to elucidate the function of genes. The work will be carried out at the Whitehead Institute/Massachusetts Institute of Technology Center for Genome Research.
Affymetrix, which is 34 per cent owned by Glaxo Wellcome, is widely acknowledged as the leader in the technology. It has already begun marketing its products in the United States, but its entry into Europe is being obstructed by Southern's patent.

In their challenge to the validity of the patent, Affymetrix and the other opponents allege that Southern's claims are not novel, not inventive, and that the specifications are insufficient to support the claims of the existing scope.

Southern disputes these claims. "I'm pretty confident that we will come through in a strong position," he says. "I think it was an original invention." Pyers Pennant, a patent attorney at Stevens, Hewlett and Perkins, the London-based law firm representing the University of Oxford, says: "Affymetrix is the main opponent - if we can answer their claims then all the others follow."

But he concedes that the opponents' claims concerning scope are "to some extent justified", adding that "the claims we were granted in Europe initially were broader than was justified". Southern has now filed amended claims of narrower scope, according to Pennant.

Conciliatory noises are being made by both parties. "I'd hope we can work this situation out without having to go through with the challenge," says Vern Norveil, a lawyer at Affymetrix. Southern agrees that both sides are willing to find common ground. "We are still talking [to Affymetrix and several of the other opponents]," he says.

In a case to be heard later this year in the Northern District Court of California, Affymetrix will face complaints that it has infringed two 1993 patents on DNA-chip technology held by another Californian company, Hyseq (see Nature Biotechnology $15,406 ; 1997)$. Hyseq is also challenging Southern's patent.

Declan Butler

\section{US farmers warm to bioengineered crops}

[WASHINGTON] As genetically altered crops create increasing controversy in Europe, US farmers are reported to be planting roughly ten times more acres this spring with engineered corn and soya beans than they did when the products were introduced last year.

About 12 per cent of US soya bean fields are being planted with modified soya beans, and about 6 per cent of corn acreage with modified corn, according to estimates by the companies that developed the crops.

"It's here to stay, I think," says Ken Fawcett, a farmer in West Branch, Iowa, who sells the altered soya beans for Asgrow, a major seed company. Fawcett says that his sales of the Monsanto company's soya beans doubled this year.

Wayne Hoener, who oversees national sales of the soya beans for Asgrow, estimates that sales have tripled this year but that demand has increased "eight or ten times".

But opponents of the crops say that the companies' rosy figures will be short-lived. "Many farmers are unfortunately buying into the public relations and marketing hoopla of Monsanto and Novartis," says Jeremy Rifkin, president of the Foundation on Economic Trends, which last autumn launched a global boycott of the engineered corn and soya beans. "I think they're going to find that there are serious problems with the crops."

Jeff Wells, co-founder of Genetic ID, an Iowa company that tests crops for genetic alterations, says that the new numbers mask a wariness among many US farmers about the implications of increasing consumer resistance to genetically altered foods in Europe (see Nature 386, 532 \& 745; 1997.)
“A significant segment of farmers don't want to be caught on the wrong side of the market," he says. As a result, "a lot" of farmers are keeping their options open by planting "a little" of the crops.

The soya beans are engineered to resist damage by Roundup, a herbicide made by Monsanto. The corn, whose lead maker is Novartis Seeds (formerly Ciba Seeds), has a gene from Bacillus thuringiensis $(B t)$, a soil bacterium. The gene codes for a protein toxic to the European corn borer, a common pest.

Monsanto claims that the increased use of its soya beans - last year they were planted in just under 2 per cent of US acreage - is a tribute to their effectiveness. The company says they allow farmers to avoid expensive pesticide regimens without losing yield. Monsanto's seeds sell for about $\$ 24$ a bag, compared to $\$ 16$ to $\$ 18$ for unmodified seeds.

Novartis Seeds says the tenfold increase in acreage of $B t$ corn planted this year is proof that the crop is winning over farmers. "If that is not a success story, then I don't know what is," says Albin Hubscher, Novartis vicepresident for marketing. He says that the company has sold out of 15 of the 18 genetically modified hybrids it produced.

Novartis says its corn accounts for $\mathbf{7 0}$ to 80 per cent of the engineered corn planted this year. It costs $\$ 124$ a bag, compared to $\$ 80$ for unengineered corn. Some farmers do not think it is worth the price. Wallie Hardie of North Dakota, who planted 150 acres of $B t$ corn last year, is not planting any this year because yield was not appreciably different from unmodified corn. 